\title{
UJI AKTIVITAS IMUNOSUPRESAN SEDIAAN SIRUP EKSTRAK ETANOL DAUN BABADOTAN (Ageratum conyzoides L.) DENGAN METODE
} ANAFILAKSIS KUTAN AKTIF

\author{
Hendy Suhendy*, Yedy Purwandi Sukmawan, Rani Rahmawati \\ Program Studi S1 Farmasi, STIKes Bakti Tunas Husada \\ *E-mail: radhwa04@gmail.com
}

Received: 07/07/2021, Revised: 29/07/2021, Accepted: 04/08/2021, Published: 18/08/2021

\begin{abstract}
ABSTRAK
Babadotan merupakan tanaman obat yang digunakan masyarakat untuk menangani penyakit kulit, luka dan alergi. Penelitian sebelumnya menunjukkan bahwa ekstrak etanol daun babadotan terbukti memiliki aktivitas imunosupresan. Tujuan penelitian ini adalah untuk menentukan aktivitas imunosupresan sirup ekstrak etanol daun babadotan terhadap mencit jantan dengan menggunakan metode anafilaksis kutan aktif. Metode penelitian bersifat eksperimen menggunakan hewan percobaan mencit jantan galur swiss webster dibagi menjadi 5 kelompok masing-masing terdiri dari 5 mencit. Kelompok kontrol positif diberikan cetirizine $10 \mathrm{mg} / 20 \mathrm{~g} \mathrm{BB}$ mencit, kelompok kontrol negatif diberikan sirup tanpa zat aktif, kelompok uji dosis 1 diberikan sediaan sirup dengan zat aktif ekstrak etanol babadotan $(2,5 \mathrm{mg} / 20 \mathrm{~g}$ BB mencit), kelompok uji dosis 2 (5 mg/20 g BB mencit) dan kelompok uji dosis $3(10 \mathrm{mg} / 20 \mathrm{~g}$ BB mencit). Pengamatan dilakukan terhadap diameter dan waktu hilangya bentolan biru. Hasil penelitian menunjukkan rata-rata diameter bentolan biru kelompok kontrol positif, kontrol negative, uji dosis 1, uji dosis 2 dan uji dosis 3 secara berturut-turut sebesar 0,$52 ; 1,60 ; 1,38 ; 0,96$ dan $0,66 \mathrm{~cm}$ dan waktu hilangnya bentolan biru sebesar 24,23; 120,53; 96,46; 72,46 dan 48,34 jam. Uji dosis 3 memiliki aktivitas imunosupresan paling baik karena secara statistik $(\mathrm{p}<0,05)$ tidak ada perbedaan signifikan data parameter yang diamati dibandingkan dengan kontrol positif. Perlu dilakukan pengujian toksisitas sediaan untuk melihat sejauh mana profil keamanannya.
\end{abstract}

Kata kunci : Anafilaksis kutan aktif, Ageratum conyzoides L, Imunosupresan, Sediaan sirup

\section{ABSTRACT}

Babadotan is a medicinal plant used by the people to treat skin diseases, wounds and allergies. Previous study has shown that the ethanolic extract of babadotan leaves have an immunosuppressant activity. The objectives of this study is to determine the immunosuppressant activity of the ethanolic extract of babadotan leaves (ageratum conyzoides L) on male mice using the active cutaneous anaphylactic reaction method. The method is an experimental study of 5 groups each consisting of 5 male swiss webster strain mice. Positive control group was given cetirizine $10 \mathrm{mg} / 20 \mathrm{~g}$ BW mice, negative control group was given syrup without active substance, dose 1 test group was given a syrup preparation with the active substance of ethanol extract of ageratum conyzoides (2,5mg/20 g BW mice), dose 2 test group (5mg/20 g BW mice), and dose 3 164 
test group (10mg/20 g BW mice). Measurements were made on the diameter and time of the disappearance of the blue bumps. The results showed that the average diameter of the blue bumps in the positive control group, negative control group, test dose 1, test dose 2 and test dose 3 were $0.52 ; 1.60 ; 1.38 ; 0.96$ and $0.66 \mathrm{~cm}$ and the time of disappearance of the blue bumps was 24.23; 120.53; 96.46; 72.46 and 48.34 hours. Test dose 3 had the best immunosuppressant activity because statistically $(p<0.05)$ there was no significant difference in the observed parameter data compared to the positive control. Need to test the toxicity of the preparation to see the extent of its safety profile.

Keywords: active cutaneous anaphylaxis, Ageratum conyzoides L., syrup preparation

\section{PENDAHULUAN}

Prevalensi kasus alergi sebagai salah satu reaksi hipersensitivitas menunjukan adanya peningkatan terutama pada anak berumur 13-14 tahun (Björkstén et al., 2008). Anafilaksis adalah salah satu reaksi hipersensitivitas akut yang melibatkan banyak organ dan berpotensi fatal. Reaksi ini diakibatkan oleh pengeluaran mediatormediator kima dari sel mast dan basofil (Kemp et al., 2008). Anafilaksis umumnya berdampak pada kulit, pernafasan, kardiovaskular dan sistem pencernaan.

Tanaman obat di negara berkembang salah satunya Indonesia telah digunakan sejak lama untuk mengobati berbagai penyakit. Salah satu tanaman yang dapat dijadikan sebagai obat imunosupresan ialah tanaman babadotan. Ekstrak etanol daun babadotan terbukti memiliki aktivitas antianafilaksis pada dosis $250 \mathrm{mg} / \mathrm{Kg} \mathrm{BB}$ mencit dengan kemungkinan mekanisme kerja melalui hambatan histamin (Suhendy, 2019).

Aktivitas daun babadotan sebagai imunosupresan menjadikan tanaman ini memiliki potensi untuk dikembangkan menjadi sediaan obat tradisional. Bentuk sediaan yang dipilih dalam hal ini adalah sirup karena berdasarkan pertimbangan organoleptik sirup bisa menutupi kekurangan aspek warna dan rasa ekstrak. Penelitian ini bertujuan untuk menentukan formulasi sediaan sirup ekstrak etanol daun babadotan yang dapat memenuhi evaluasi sediaan dan evaluasi aktivitas imunosupresannya.

\section{METODE PENELITIAN}

\section{Alat dan Bahan}

Alat pengering simplisia, spuit $1 \mathrm{ml}$ dan $3 \mathrm{ml}$, timbangan hewan, kandang mencit, jangka sorong (Vernier Caliper), rotary evaporator (IKA Basic), beaker glass (Pyrex), timbangan analitik (Mark-M5-ion), pipet tetes, tabung reaksi (Pyrex), 
Erlenmeyer (Pyrex), gelas ukur (Pyrex), kaca arloji (Pyrex), krus porselen, cawan evaporasi $(R R C)$, Shake Waterbath (Memmert®), batang pengaduk, botol semprot, aluminium foil, plastic wrap, mortar, botol sirup, mesh 40, blender (Philips), seperangkat alat destilasi azeotrope, tanur.

Simplisia daun babadotan, putih telur, aqua pro injeksi, etanol 96\%, etanol $95 \%, \mathrm{CHCl}_{3}, \mathrm{HCl}$, pereaksi mayer $\left(\mathrm{HgCl}_{2}\right.$, $\mathrm{KI}$, aquades), pereaksi dragendorff (bismuth nitrat, $\left.\mathrm{CH}_{3} \mathrm{COOH}, \mathrm{KI}\right)$, logam $\mathrm{Mg}$, amil alcohol, gelatin, $\mathrm{FeCl}, \mathrm{KOH} 5 \%$, vanillin, $\mathrm{H}_{2} \mathrm{SO}_{4},\left(\mathrm{CH}_{3} \mathrm{CO}\right)_{2} \mathrm{O}$, aqua pro injeksi, tablet Cetripim (PT. PIM Pharmaceuticals), Evans blue (Sigma-Aldrich), propilen glikol, nipagin, essence mint, sirupus simplex.

\section{Jalannya Penelitian}

1. Penyiapan Bahan

Daun Babadotan (Ageratum conyzoides L.) diperoleh di sekitar pekarangan rumah di Desa Raksabaya, Kecamatan Cimaragas, Kabupaten Ciamis Jawa Barat.

2. Determinasi Tanaman

Determinasi tanaman dilakukan di Herbarium Jatinangor FMIPA Universitas Padjadjaran.

3. Pengujian karakteristik simplisia 166
Pengujian karakteristik simplisia meliputi penetapan kadar air menggunakan metode azeotrop dimana 5 gram ekstrak ditambahkan ke dalam toluen jenuh air, penetapan kadar abu total dilakukan dengan pemanasan sampel sebanyak 2 gram pada suhu $500-600^{\circ} \mathrm{C}$ sampai menjadi abu, penetapan kadar sari larut air dan penetapan kadar sari larut etanol dilakukan dengan maserasi selama 18 jam, maserat disaring dan filtrat diuapkan sampai kering kemudian dipanaskan pada suhu $105^{\circ} \mathrm{C}$.

4. Pengujian karakteristik ekstrak

Pengujian karakteristik ekstrak meliputi penetapan kadar air dengan prosedur yang sama seperti pada penentuan kadar air simplisia dan penetapan bobot jenis ekstrak dengan menggunakan piknometer.

5. Penapisan fitokimia

Penapisan fitokimia sampel untuk mengetahui golongan senyawa kimia yang terkandung dalam simplisia dan ekstrak daun babadotan yang meliputi pemeriksaan alkaloid, flavonoid, tannin, saponin, steroid/terpenoid.

6. Pembuatan Ekstrak

Sebanyak 500 gram serbuk daun babadotan dimaserasi menggunakan etanol 96\% selama 3 hari dengan pengadukan setiap 8 jam sekali dengan penggantian pelarut 
setiap 24 jam sekali. Maserat disaring dan dipekatkan dengan rotary evaporator. pelarut yang masih terkandung didalam ekstrak diuapkan kembali menggunakan waterbath.

7. Optimasi Formula Sediaan Sirup Tanpa Zat Aktif Ekstrak Etanol Babadotan

Tabel 1. Formulasi sirup tanpa zat aktif

\begin{tabular}{cccc}
\hline Bahan & formula & Formula & Formula \\
& $\mathbf{1}$ & $\mathbf{2}$ & $\mathbf{3}$ \\
\hline Propilenglikol & $20 \%$ & $15 \%$ & $25 \%$ \\
Nipagin & $0,4 \%$ & $0,1 \%$ & $0,2 \%$ \\
Essence mint & $0,5 \%$ & $0,5 \%$ & $0,5 \%$ \\
Sirup simpleks & ad & ad $60 \mathrm{~mL}$ & $\mathrm{ad} 60 \mathrm{~mL}$ \\
& $60 \mathrm{~mL}$ & & \\
\hline
\end{tabular}

(Sugarda et al., 2019; Rowe, 2006)

Optimasi sediaan sirup dibuat sebanyak tiga formula dengan variasi konsentrasi propilenglikol dan nipagin. Kemudian dilakukan pemilihan formula untuk dilanjutkan dengan pembuatan sirup dengan zat aktif ekstrak etanol babadotan dari hasil evaluasi terbaik.

8. Pembuatan Sediaan Sirup dan Evaluasi

\section{Sediaan Tanpa Zat Aktif}

Timbang bahan-bahan sesuai yang dibutuhkan, dan tara botol sediaan sampai 60mL. kemudian buat sirupus simpleks dengan melarutkan sukrosa dalam aquadest. Larutkan nipagin secukupnya dalam propilenglikol aduk sampai homogen, setelah homogen dilarutkan dengan sirup simpleks secukupnya, tambahkan essence mint kemudian sediaan dimasukkan ke dalam botol dan ditambahkan sisa sirupus simplek hingga volumenya $60 \mathrm{~mL}$. Evaluasi sediaan terdiri dari pemeriksaan organoleptik, viskositas, pemeriksaan $\mathrm{pH}$, bobot jenis dan uji volume terpindahkan.

9. Pembuatan Sediaan Sirup dan Evaluasi Sediaan Dengan Zat Aktif Ekstrak Etanol Babadotan

Formula terpilih dibuat sediaan sirup dengan penambahan zat aktif ekstrak etanol daun babadotan dan dilakukan evaluasi sediaan dengan prosedur yang sama pada pembuatan sediaan sirup dan evaluasi sediaan tanpa zat aktif.

10. Uji Aktivitas Anafilaksis

Mencit jantan galur swiss webster dibagi menjadi 5 kelompok masing-masing terdiri dari 5 mencit. Kelompok kontrol positif diberikan cetirizine $10 \mathrm{mg} / 20 \mathrm{~g} \mathrm{BB}$ mencit, kelompok kontrol negatif diberikan sirup tanpa zat aktif, kelompok uji dosis 1 diberikan sediaan sirup dengan zat aktif ekstrak etanol babadotan $(2,5 \mathrm{mg} / 20 \mathrm{~g}$ BB mencit), kelompok uji dosis 2 (5 mg/20 g BB mencit) dan kelompok uji dosis 3 (10 mg/20 g BB mencit). Pada tahap awal dilakukan sensitisasi terlebih dahulu pada tiap 
kelompok untuk menstimulasi reaksi alergi pada hewan percobaan, tahap sensitisasi dilakukan selama 2 siklus (per 7 hari per siklus). Semua kelompok diberikan ovalbumin $\quad(5 \mathrm{ml} / \mathrm{kg} \quad \mathrm{BB}) \quad$ secara intraperitonial. Setelah tahap sensitisasi pada tiap kelompok, dilanjutkan pada tahap penantangan. Sehari sebelum percobaan penantangan (sehari sebelum periode sensitisasi berakhir) bagian punggung hewan dicukur bagi dalam beberapa sektor penyuntikan. Pada hari penantangan, diberikan larutan evans blue 0,25\% (0,1 mL) secara intravena sebagai pewarna untuk mempermudah pengamatan bentolan. Setengah jam kemudian suntikan secara intrakutan pada tiap sektor larutan putih telur $10 \%$ sebanyak $0,1 \mathrm{ml} / \mathrm{BB}$ mencit untuk memicu reaksi alergi sehingga akan terbentuk bentolan biru. 15 menit setelah terbentuk bentol diberikan perlakuan pada tiap kelompok, yaitu kontrol positif diberikan cetirizine $10 \mathrm{mg}$, kontrol negatif diberikan sediaan sirup tanpa zat aktif, dosis 1 (2,5mg/BB mencit), dosis 2 (5mg/BB mencit), dan dosis 3 (10mg/BB mencit). Kemudian dilakukan pengamatan dan pengukuran terhadap sektor-sektor tersebut pada waktu 60 menit, kemudian dilanjutkan pengamatan setiap hari selama 7 hari. 168
Pengamatan meliputi diameter bentolan biru dan sampai waktu menghilangnya bentolan (Suhendy, 2019).

\section{Analisis Data}

Analisis yang digunakan pada penelitian ini yaitu analisis statistik menggunakan metode ANOVA dan diteruskan dengan LSD menggunakan program SPSS dengan Confidence Interval $95 \%$.

\section{HASIL DAN PEMBAHASAN}

1. Determinasi Tanaman

Determinasi tanaman dilakukan untuk mengetahui suku dan jenis dari babadotan (Ageratum conyzoides L.). Hasil determinasi menunjukkan bahwa sampel yang digunakan benar merupakan tanaman babadotan sesuai dengan nomor 54/HB/01/2021.

2. Karakterisasi Simplisia

Tabel 1. Hasil karakterisasi simplisia

\begin{tabular}{ccc}
\hline Parameter & Hasil (\%) & Syarat (FHI) \\
\hline Kadar Air & 7,3 & $<10 \%$ \\
Kadar Abu & 8,66 & $<10 \%$ \\
Kadar Sari & 25,92 & $>11,4 \%$ \\
Larut Air & & \\
Kadar Sari & 25,78 & $>17,5 \%$ \\
Larut Etanol & & \\
\hline
\end{tabular}

Keterangan : FHI = Farmakope Herbal Indonesia

Karakterisasi simplisia dilakukan untuk mengetahui karakter simplisia yang digunakan serta untuk mengetahui telah 
masuk tidaknya pada persyaratan yang direkomendasikan Pengujian karakteristik simplisia daun babadotan terlihat pada Tabel 2 dimana menunjukkan hasil yang cukup baik dengan parameter yang paling penting yaitu kadar air ekstrak tidak melebihi $10 \%$ sesuai persyaratan yang ditetapkan (FHI). Kadar air yang tinggi $(>10 \%)$ dapat mengakibatkan penurunan kualitas dan mencetuskan pertumbuhan fungi atau bakteri. Sedangkan dalam penentuan kadar abu total untuk mengetahui adanya kandungan unsur mineral atau pengotor seperti silika atau pasir (Andhika et al, 2017). Selain itu diketahui bahwa ekstrak Ageratum conyzoides L lebih terlarut dalam air dibandingkan dalam etanol.

\section{Karakterisasi Ekstrak}

Tabel 2. Hasil karakterisasi ekstrak

\begin{tabular}{ccc}
\hline Parameter & Hasil & Syarat \\
\hline Kadar Air & $6 \%$ & $5-30 \% *$ \\
Bobot Jenis & $0,79 \mathrm{~g} / \mathrm{mL}$ & Tidak ada** \\
\hline
\end{tabular}

Keterangan:

*: Voight, 1994

**: BPOM RI 2014

Karakterisasi ekstrak dilakukan juga untuk mengetahui karakteristik ekstrak daun babadotan, karakteristik yang dilakukan yaitu kadar air ekstrak dan juga bobot jenis. Kadar air ekstrak bertujuan untuk menetapkan residu air, dengan parameter 5$30 \%$, sedangkan bobot jenis didefinisikan sebagai perbandingan kerapatan suatu zat terhadap kerapatan air dengan nilai massa per satuan volume. Penentuan bobot jenis ini bertujuan untuk memberikan gambaran kandungan kimia yang terlarut pada suatu ekstrak (Depkes RI, 2000).

\section{Penapisan Fitokimia}

Tabel 3. Hasil Skrining Fitokimia Simplisia dan Ekstrak

\begin{tabular}{lcc}
\hline $\begin{array}{c}\text { Golongan } \\
\text { senyawa }\end{array}$ & Simplisia & Ekstrak \\
\hline Alkaloid & + & + \\
Flavonoid & + & + \\
Saponin & + & - \\
Tannin & + & + \\
Kuinon & + & + \\
Steroid & + & + \\
/triterpenoid & & \\
Keterangan: & &
\end{tabular}

(+) : mengandung senyawa yang diuji

(-) : tidak mengandung senyawa yang diuji

Dari hasil penapisan fitokimia terlihat bahwa pada tabel 3 menunjukkan bahwa simplisia mengandung semua senyawa golongan metabolit yang diujikan sedangkan untuk ekstrak hanya tidak mengandung senyawa golongan saponin. Semua golongan senyawa metabolit sekunder yang ada pada ekstrak diduga merupakan memberikan kontribusi terhadap aktivitas imunosupresan terutama flavonoid. Adanya perbedaan hasil antara simplisia dan ekstrak disebabkan karena beberapa faktor yaitu saat melakukan maserasi, saat penarikan zat aktif belum sempurna dan pada saat melakukan 
pemekatan dengan rotary evaporator zat aktif rusak dan tidak terdeteksi karena suhu sehingga berpengaruh pada perbedaan hasilnya (Rivai et al, 2019).

5. Randemen Ekstrak

Tabel 4. Hasil Rendemen Ekstrak

\begin{tabular}{cccc}
\hline $\begin{array}{c}\text { Berat } \\
\text { Hasil } \\
\text { Ekstrak }\end{array}$ & $\begin{array}{c}\text { Berat } \\
\text { simplisia }\end{array}$ & $\begin{array}{c}\text { Hasil } \\
\text { Rendemen }\end{array}$ & $\begin{array}{c}\text { Syarat } \\
\text { FHI }\end{array}$ \\
\hline $51,06 \mathrm{~g}$ & $500 \mathrm{~g}$ & $10,21 \%$ & $>9,6 \%$
\end{tabular}

Keterangan: $\mathrm{FHI}=$ Farmakope Herbal Indonesia

Hasil ekstrak kental yang didapat yaitu sebanyak 51,06 gram dengan rendemen ekstrak yaitu 10,21\%. Jika dibandingkan dengan riset penelitian (Suhendy, 2019) yaitu 26,99\% maka, hasil ekstrak kental penelitian ini lebih kecil. Nilai rendemen yang tinggi, menunjukkan komponen bioaktif yang terkandungnya banyak. Adanya perbedaan hasil rendemen bisa diakibatkan oleh perbedaan tempat tumbuh sumber simplisia yang dipengaruhi oleh suhu, cahaya, dan juga ketinggian tempat tumbuh yang berpengaruh pada kandungan kimia yang dihasilkan. Selain itu, ukuran partikel bahan juga bisa mempengaruhi hasil dari ekstrak kental yang dihasilkan karena semakin kecilnya ukuran partikel bahan yang diekstrak maka semakin memudahkan pelarut masuk dan jika ukuran partikel bahan besar, maka semakin sulit pelarut menembus dinding sel bahan 170 sehingga menyebabkan bahan aktif yang terekstrak sedikit (Dewitasari, 2017).

6. Evaluasi Sediaan Sirup Tanpa Zat Aktif Tabel 5. Hasil Evaluasi Sediaan Formula

\begin{tabular}{|c|c|c|c|c|}
\hline \multirow{2}{*}{$\begin{array}{c}\text { Parameter } \\
\text { Uji }\end{array}$} & \multicolumn{3}{|c|}{ Formula } & \multirow{2}{*}{ Syarat } \\
\hline & 1 & 2 & 3 & \\
\hline \multicolumn{5}{|l|}{ Organoleptik: } \\
\hline Bentuk & Cair & Cair & Cair & Cair \\
\hline Warna & Bening & Bening & Bening & Bening \\
\hline $\mathrm{Bau}$ & Mint & Mint & Mint & $\begin{array}{c}\text { Tidak ada bau, } \\
\text { jika tidak } \\
\text { ditambahkan } \\
\text { essence }\end{array}$ \\
\hline Rasa & Mint & Mint & Mint & $\begin{array}{c}\text { Tidak ada rasa, } \\
\text { jika tidak } \\
\text { ditambahkan } \\
\text { essence }\end{array}$ \\
\hline $\mathrm{pH}$ & 5 & 5 & 5 & $4-8^{*}$ \\
\hline Volume & $100 \%$ & $98 \%$ & $96 \%$ & $>95 \%{ }^{* *}$ \\
\hline \multicolumn{5}{|l|}{ Terpindahkan } \\
\hline Bobot Jenis & $\begin{array}{c}1,2 \\
\mathrm{~g} / \mathrm{mL}\end{array}$ & $\begin{array}{c}2,3 \\
\mathrm{~g} / \mathrm{mL}\end{array}$ & $\begin{array}{c}1,1 \\
\mathrm{~g} / \mathrm{mL}\end{array}$ & $1,3 \mathrm{~g} / \mathrm{Ml}^{* * *}$ \\
\hline \multirow[t]{2}{*}{ Viskositas } & 30,0 & 40,0 & 48,0 & $27-396 \mathrm{cps}^{* *}$ \\
\hline & cps & cps & cps & \\
\hline
\end{tabular}

Formula 1 dipilih untuk dibuat sediaan sirup dengan penambahan zat aktif ekstrak etanol babadotan karena dari semua parameter yang diujikan, formula tersebut menunjukkan hasil yang hampir memenuhi nilai standar.

7. Evaluasi Sediaan Sirup Dengan Zat Aktif

Hasil evaluasi sediaan sirup dengan zat aktif ekstrak etanol babadotan menunjukkan hasil yang hampir tidak berbeda dengan hasil evaluasi pertama pada formula 1 atau formula terpilih. Hal ini menunjukkan formula sirup sama baiknya setelah ditambahkan dengan zat aktif. 
Tabel 6. Hasil Evaluasi Sediann Formula 1

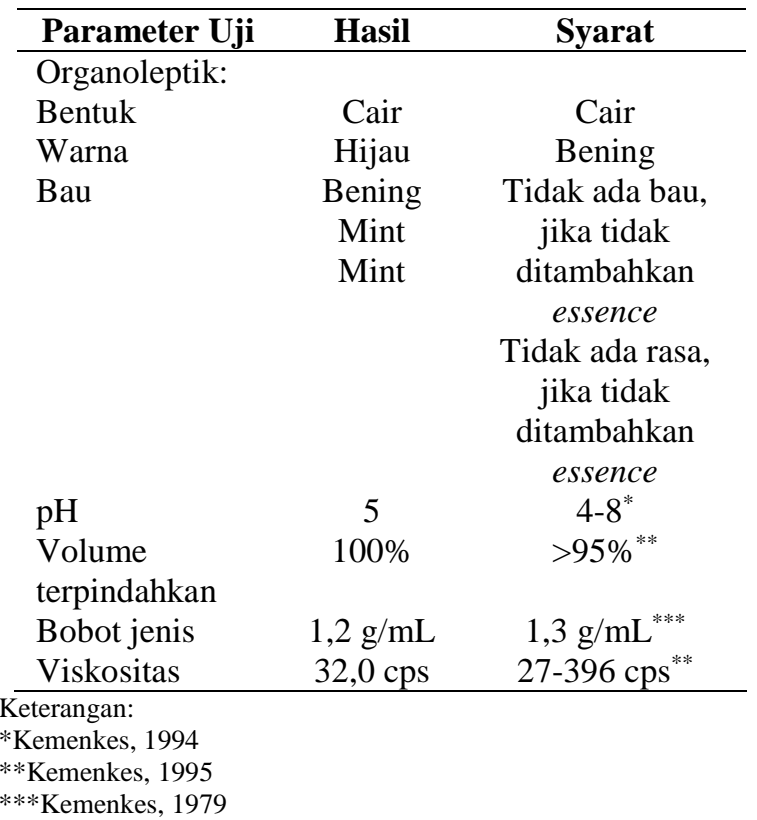

\section{Waktu Timbul Bentol}

Tabel 7. Rataan \pm waktu timbul bentolan biru (menit)

\begin{tabular}{|c|c|c|}
\hline $\begin{array}{c}\text { Kelompok } \\
\text { Dosis Uji }\end{array}$ & $\begin{array}{c}\text { Rata rata } \\
\text { waktu timbul } \\
\text { (menit) }\end{array}$ & $P<0,05$ \\
\hline Kontrol positif & $28,35 \pm 0,09$ & \\
\hline Kontrol negatif & $28,20 \pm 0,07$ & 0,806 \\
\hline Dosis I & $28,35 \pm 0,10$ & \\
\hline Dosis II & $28,41 \pm 0,08$ & \\
\hline Dosis III & $28,38 \pm 0,08$ & \\
\hline
\end{tabular}

Dari tabel diatas bisa dilihat bahwa waktu timbulnya bentol semua mencit pada masing-masing kelompok tidak jauh berbeda sehingga bisa dikatakan kondisi sistem imun dan treatment sensitisasi sudah sesuai, dan juga dijadikan indikasi kapan sediaan uji diberikan. Sediaan uji diberikan 15 menit setelah terbentuk bentolan biru.

Induksi yang digunakan adalah putih telur karena telur dapat menyebabkan alergi karena mengandung protein, histamine, dan igE yang dapat menstimulasi timbulnya hipersensitivitas dalam tubuh manusia (Caubet \& Wang 2011). igE dan histamin termasuk kedalam tipe pertama (reaksi anafilaksis) alergi yang terjadi karena adanya interaksi sel antibodi igE dan alergan menyebabkan aktivasi dari sel mast dan basofil. Sel mast dan basofil yang teraktivasi menyebabkan peradangan (Riwayanti, 2015).

\section{Diameter Bentol}

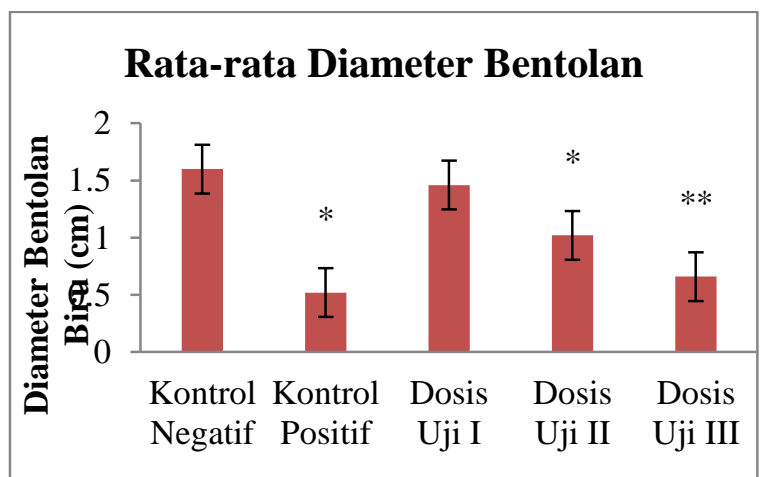

Gambar 1. Diagram Diameter Bentolan Keterangan:

* = Terdapat perbedaan yang signifikan $(\mathrm{p}<0,05)$ dibandingkan dengan kontrol negatif

** = Tidak terdapat perbedaan yang signifikan dibandingkan dengan kelompok positif $(p>0,05)$

Hasil penelitian menunjukkan ratarata diameter bentolan biru kelompok kontrol positif, kontrol negatif, uji dosis 1, uji dosis 2 dan uji dosis 3 secara berturut-turut sebesar 
0,$52 ; 1,60 ; 1,38 ; 0,96$ dan $0,66 \mathrm{~cm}$ yang diagramnya dapat dilihat pada gambar 1 .

Berdasarkan hasil statistik menunjukan bahwa uji dosis I tidak berbeda signifikan dengan kelompok kontrol negatif $(>0,05)$ artinya tidak memiliki aktivitas antianafilaksis. Uji dosis II memiliki perbedaan bermakna $(\mathrm{p}<0,05)$ dibandingkan dengan kelompok kontrol negatif, tetapi tidak lebih baik dari kelompok uji dosis III. sedangkan uji dosis III tidak berbeda signifikan dengan kontrol positif $(>0,05)$ artinya aktivitas uji dosis III sama baiknya dengan kontrol positif. Hal ini karena aktivitas antianafilakis yang ditunjukkan oleh ekstrak Ageratum conyzoides kemungkinan akibat antihistaminnya dengan kandungan senyawa flavonoid yang terkandung pada daun babadotan dengan mekanisme kerja dapat menghambat reseptor $\mathrm{H} 1$ dan menstabilkan sel mast melalui hambatan kalsium influx (Kempuraj et al, 2005; Park et al, 2008; Taur \& Patil, 2011 ; (Singh et a., 2013).

10. Waktu hilang Bentol

Rata-rata waktu hilangnya bentolan biru kelompok kontrol positif, kontrol negative, uji dosis 1, uji dosis 2 dan uji dosis 3 secara berturut-turut sebesar 24,23; 120,53;
96,46; 72,46 dan 48,34 jam yang diagramnya dapat dilihat pada gambar 2 .

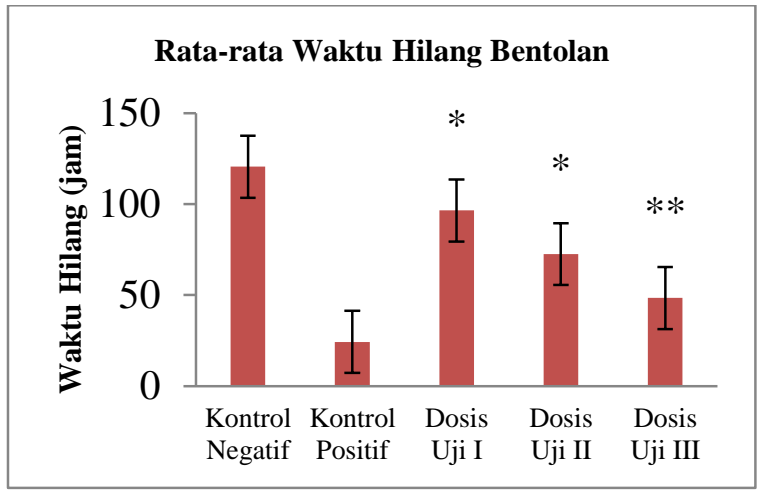

Gambar 2. Diagram rata-rata waktu hilang bentolan

Keterangan:

* = Terdapat perbedaan yang signifikan $(\mathrm{p}<0,05)$ dibandingkan dengan kontrol negatif

** = Tidak terdapat perbedaan yang signifikan dibandingkan dengan kelompok positif(p>0,05)

Berdasarkan hasil analisis statistik menunjukan bahwa kelompok uji dosis I, uji dosis II dan uji dosis III memiliki perbedaan bermakna bila dibandingkan dengan kelompok kontrol negatif $(\mathrm{p}<0,05)$. Artinya semua kelompok uji memiliki aktivitas yang berbeda tetapi, uji dosis I tidak lebih baik bila dibandingkan dengan uji dosis II. Uji dosis II tidak lebih baik juga bila dibandingkan dengan uji dosis III. Adanya aktivitas dalam penurunan bentolan menunjukkan bahwa reaksi pelepasan histamin dan mediator inflamasi lainnya dapat ditekan. 


\section{KESIMPULAN}

Berdasarkan penelitian, formula 1 dengan dosis uji 3 (10 mg/ $20 \mathrm{~g} \mathrm{BB}$ mencit) sediaan sirup ekstrak etanol daun babadotan (Ageratum conyzoides $\mathrm{L}$ ) memenuhi evaluasi parameter organoleptik, $\mathrm{pH}$, volume terpindahkan dan viskositas serta memiliki aktivitas imunosupresan paling baik karena secara statistik $(\mathrm{p}<0,05)$ tidak ada perbedaan signifikan data diameter dan waktu hilangnya bentolan biru dibandingkan dengan kontrol positif.

\section{DAFTAR PUSTAKA}

Andhika D, Oon K, Ella N. Formulasi Dan Uji Sediaan Masker Anti Jerawat Kayu Manis (Cinamomum burmani (Nees\& $\mathrm{T}$ Nees).Tersedia di perpustakaan Fmipa.unpak.ac.id/fileejurnal\%200661 09044.docx (Diakes tanggal 25 juli 2017).

Björkstén B, Clayton T, Ellwood P, Stewart A, Strachan D. (2008). Worldwide time trends for symptoms of rhinitis and conjunctivitis: Phase III of the International Study of Asthma and Allergies in Childhood. Pediatric Allergy and Immunology, 19 (2), 110124.

Caubet., J. C., \& Wang J (2011) Curents
Understanding of Egg Allergy. Pediatric Clinics Of North America, 58920, 427-443

Depkes RI. (2000) Parameter Standar Umum Ekstrak Tumbuhan Obat, Cetakan Pertama, 3-11, 17-19, Dikjen POM, Direktorat Pengawasan Obat Tradisional.

Dewitasari W., Rumiyanti I (2017). Randemen dan Skrining Fitokimia pada Ekstrak Daun Sansiviera sp. Rendemen and Phytochemical Streening using Leaf extract of Sanseviera Sp. Jurnal Penelitian Pertanian Terapan, 17(3), 197-202

Kemenkes. (1979). Farmakope Indonesia Edisi Ketiga, : Departemen Kesehatan Republik Indonesia, Jakarta.

Kemenkes. (1995). Farmakope Indonesia

Edisi Keempat, : Kementrian Kesehatan Republik Indonesia, Jakarta. Kemp SF, and Lockey RF. (2002), Anaphylaxis: a review of cause and mechanisms. J Allergy Clin Immunol, 110 (3), 341-348

Kempuraj D, Madhappan B, Christodoulou S, Boucher W, Cao J, Papadopoulou N, Cetrulo CL, Theoharides TC. (2005). Flavonols inhibit proinflammatory mediator release, intracellular calcium 
ionlevels and protein kinase $\mathrm{C}$ theta phosphorylation in human mast cell. $\mathrm{Br}$ J pharmacol, 145(7), 934-44.

Park HH, Lee S, Son HY, Park SB, Kim MS, Choi EJ, Singh TS, Ha JH, Lee MG, Kim JE, Hyun MC, Kwon TK, Kim YH, Kim SH. (2008). Flavonoids inhibit histamin release and expression of proinflammatory cytokines in mast cells. Archieves of Pharmaceutical Research, 31(10), 3-11.

Rivai H., Misfadhila, S., Sari., K.L. (2019). Analisis Kualitatif dan Kuantitatif Kandungan Kimia dari Ekstrak Heksan, Aseton, Etanol dan Air dari Rimpang Kunyit (Curcuma domestica Val). Universitas Andalas, Padang.

Riwayanti. (2015). Reaksi hipersensitivitas atau alergi. Reaksi Hipersensitivitas atau Alergi. Jurnal Keluarga Sehat Sejahtera, 13 (2), 22-27

Singh, S. B., Devi, W. R., Marina, A., Devi, W. I., Swapana, N., \& Singh, C. B. (2013). Ethnobotany, phytochemistry and pharmacology of Ageratum conyzoides Linn (Asteraceae). Journal of Medicinal Plants Research, 7(8), 371-385.

Sugarda, W.O. Dewi, K.D.C. Putra, K.W.A Yogiswara, M.B. Sukawati, C.B.A. C.
Sutresna, P.A.R. Dewi, N.L.G.J. Arisanti, C.I.S. Yustiantara, P.S (2019). Formulasi Sediaan Sirup Peningkat Imunitas Dari Herba Meniran (Phylantus niruri L.). Jurnal Kimia, 13(2), 139-144.

Suhendy, H. (2019). Aktivitas Immunomodulator Ekstrak Etanol Daun Babadotan [Ageratum Conyzoides (L.)] Terhadap Mencit Jantan Galur Swiss Webster. Journal of Pharmacopolium, 2(1), 9-14. 